\title{
Streptozotocin Diabetes: A Glucoreceptor Dysfunction Affecting D Cells as Well as B and A Cells
}

\author{
K. Hermansen, H. Ørskov, and S. E. Christensen \\ Second University Clinic of Internal Medicine, Kommunehospitalet, Aarhus, Denmark
}

Summary. Somatostatin release from the isolated pancreas of 3 normal and 6 streptozotocin diabetic dogs has been measured in response to various stimuli to determine whether abnormalities in somatostatin release are present in the diabetic pancreas. Simultaneous measurement of glucagon secretion was also made. In the pancreas from normal dogs increases in perfusate glucose from 25 to $200 \mathrm{mg} / 100 \mathrm{ml}$ induced a $2-3$ fold increase in somatostatin release and a two thirds decrease in glucagon secretion. In contrast, in the diabetic pancreas glucose caused no change in the secretion of the two hormones. In the diabetic pancreas addition of insulin to the perfusate $(25,000 \mu \mathrm{U} / \mathrm{ml})$ for periods from 10 to 75 minutes aimed at restoring normal extracellular insulin levels in the islets failed to restore either somatostatin or glucagon secretion to normal. In contradistinction to the lack of effect of glucose, the somatostatin and glucagon responses to arginine $(5 \mathrm{mmol} / \mathrm{l})$, isoproterenol $(2 \mathrm{ng} / \mathrm{ml})$ and calcium $(5 \mathrm{mmol} / \mathrm{l})$ were normal in the diabetic pancreas. The data suggests the presence of a selective glucoreceptor abnormality of the D as well as of $\mathrm{B}$ and A cells in the streptozotocin diabetic dog.

Key words: Diabetes, streptozotocin, somatostatin release, glucagon release, isolated canine perfused pancreas, glucoreceptor, glucose, arginine, isoproterenol, calcium, radioimmunoassay.

The finding that somatostatin inhibits insulin [1], glucagon [2], and pancreatic polypeptide (PP) secretion [3], alters blood glucose levels [4], and is released from the D-cells of the islets of Langerhans in response to glucose [5-7] and glucagon [8,9] points to a role of somatostatin as a potential physiological regulator of islet hormone secretion.

In experimental diabetes fasting plasma somatostatin levels are significantly increased [10]. This observation, coupled with the demonstration of both an increase in the islet and pancreatic contents of somatostatin $[11,12]$ and an augmentation of the Dcell number in insulin deficient diabetes [13], suggests that abnormalities of somatostatin secretion could be present in diabetes.

This report deals with the D- and A-cell function in the isolated, perfused pancreas from dogs treated acutely with streptozotocin. The effect of glucose modulation without and during insulin infusion was investigated and compared with the effect of other stimuli on somatostatin secretion.

\section{Material and Methods}

\section{Animals and Perfusion System}

Nine male mongrels, weighing $16-25 \mathrm{~kg}$ were used as pancreas donors. In 6 of the dogs diabetes was induced with streptozotocin $(50 \mathrm{mg} / \mathrm{kg} \mathrm{IV})$, dissolved immediately beforehand in a citratephosphate buffer ( $\mathrm{pH} 4.5$ ). Blood samples were obtained from these animals after an overnight fast, just before streptozotocin infusion. The diabetic dogs were maintained on a normal diet without insulin treatment for periods varying from 3 to 5 days until the operation. After an overnight fast and just before anaesthesia blood samples were again collected from all diabetic animals.

Venous blood obtained from a foreleg was sampled into tubes containing $1000 \mathrm{KIU} / \mathrm{ml}$ Trasylol ${ }^{\circledast}$ (FBA Pharmaceutical, N. Y.) and $3 \mathrm{mg}$ EDTA $/ \mathrm{ml}$ and kept on ice for up to $20 \mathrm{~min}$. The plasma was then separated by centrifugation and stored at $-18^{\circ} \mathrm{C}$ until assayed for glucose and glucagon.

Normal and streptozotocin diabetic dogs were subjected to the following procedure after an overnight fast. The technique for isolation of the pancreas and the perfusion system have been described in detail [14]. In brief, the preparation consisted of the pancreas and the proximal $10 \mathrm{~cm}$ of the attached duodenum. A non-recirculating medium of Krebs-Ringer buffer ( $\mathrm{pH}$ 7.4) con- 

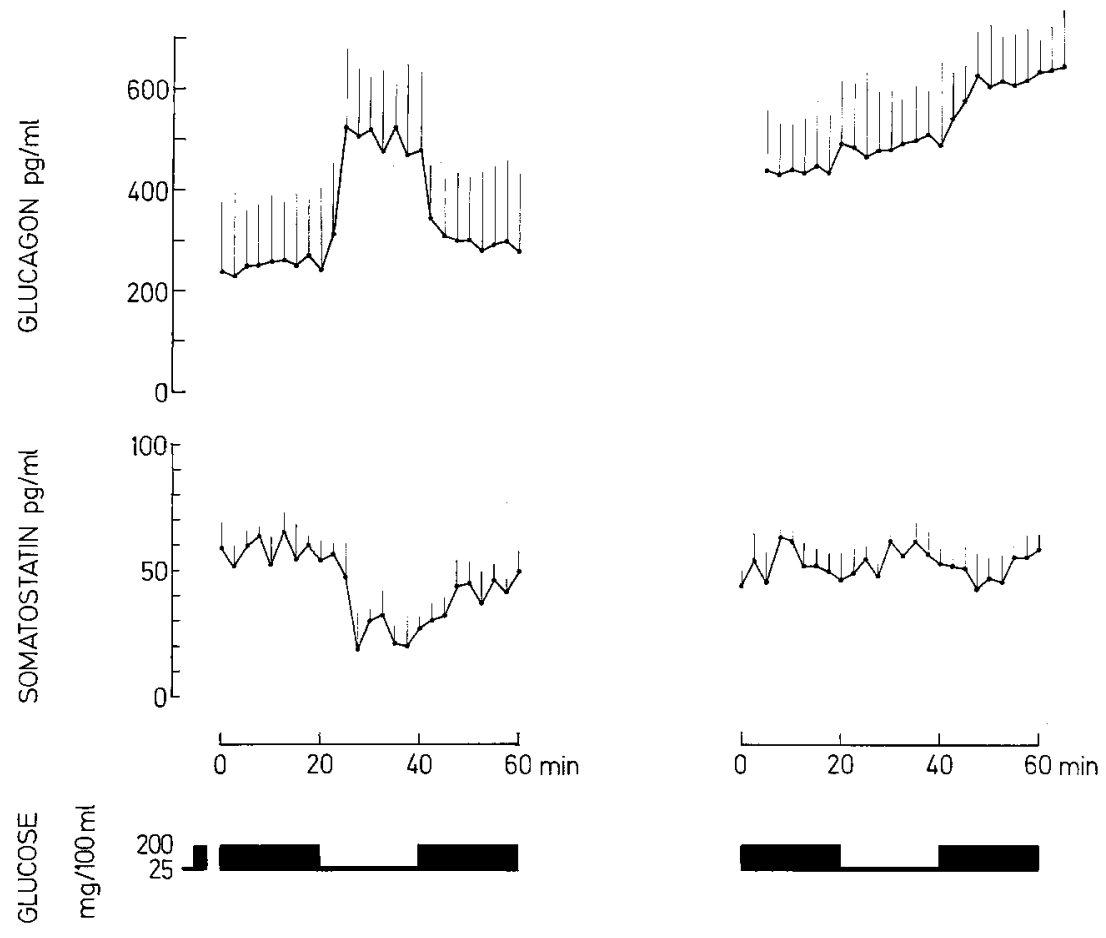

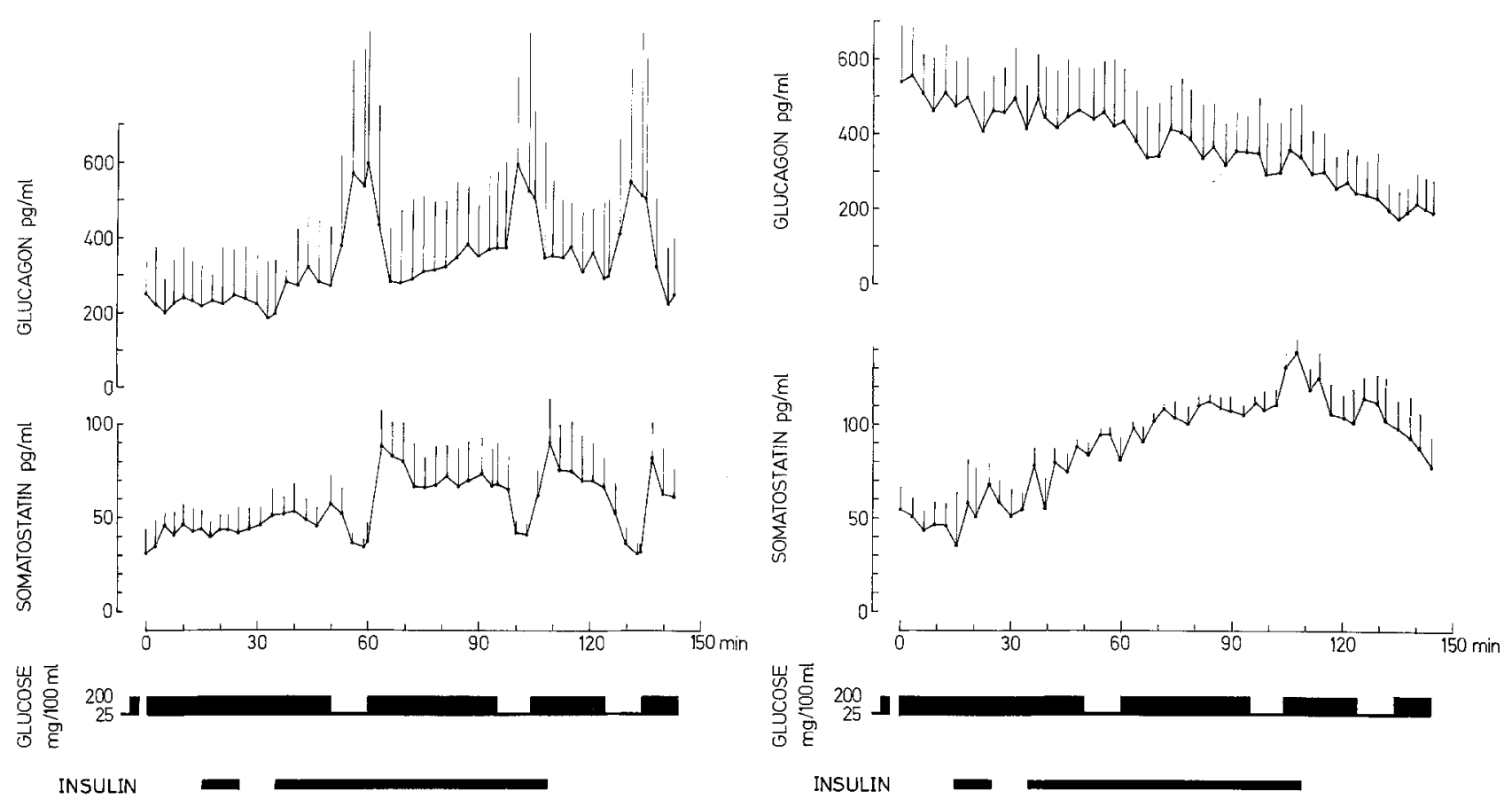

Fig. 1. Somatostatin and glucagon secretion from the isolated pancreas of normal (left part $)(\mathrm{n}=3)$ and streptozotocin diabetic $\operatorname{dogs}(n=4)$ (right part) during variation in glucose concentration from 200 to $25 \mathrm{mg} /$ $100 \mathrm{ml}$. Results are given as mean \pm SEM

Fig. 2. Somatostatin and glucagon secretion from the isolated pancreas of normal $(n=3)$ (left part) and streptozotocin diabetic dogs $(\mathrm{n}=3$ ) (right part) during 10 and $75 \mathrm{~min}$ infusions of exogenous insulin $(25,000 \mu \mathrm{U} / \mathrm{ml})$. The glucose concentration varied between 200 and $25 \mathrm{mg} / 100 \mathrm{mg}$. Results are given as mean $\pm \mathrm{SEM}$

taining dextran (molecular weight 75,000) $40 \mathrm{~g} / 1$, bovine albumin $2 \mathrm{~g} / \mathrm{l}$, glutamate, fumarate, and pyruvate, each at a concentration of $5 \mathrm{mmol} / 1$, was introduced through the splenic and the coeliac arteries, and the total portal effluent was collected every min. The perfusion pressure $(30-40 \mathrm{mmHg})$ and the perfusion flow
$(18-20 \mathrm{ml} / \mathrm{min})$ were constantly monitored and remained unchanged.

Substances to be examined were added to the basic perfusion medium by means of constant infusion syringes. The following substances were given: $\mathbf{L}$-arginine hydrochloride, $\mathbf{L}$-isoproterenol 

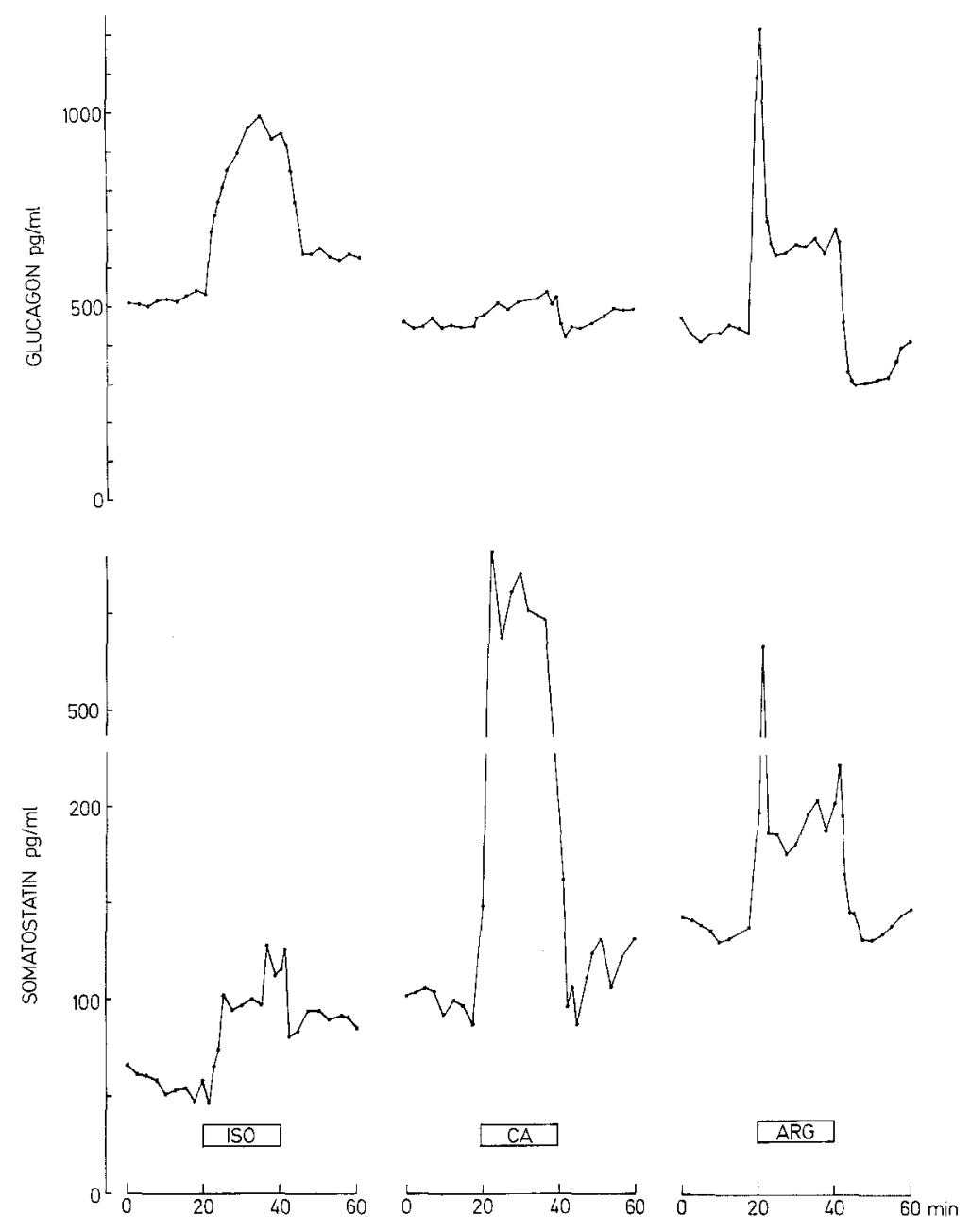

Fig. 3. Effect of isoproterenol (ISO) ( $2 \mathrm{ng} / \mathrm{ml})$, calcium (CA) $(5 \mathrm{mmol} / \mathrm{l})$, and arginine (ARG) $(5 \mathrm{mmol} / \mathrm{l})$ upon somatostatin and glucagon secretion in streptozotocin diabetes. The glucose concentration was $100 \mathrm{mg} / 100 \mathrm{ml}$. 1 of 2 experiments

(Sigma Chemical Comp., St. Louis, Mo.) and calcium chloride (Merck, Darmstadt).

\section{Analytical Methods}

Glucagon [15] and somatostatin [7] were measured by single antibody radioimmunoassay as previously described. In the glucagon assay a highly specific antiserum (K 964, a gift from Lise Heding, NOVO Research Lab., Copenhagen) was used. Glucose was determined with a glucose-oxidase method [16]. Urine was tested for ketones by Ketostix ${ }^{\circledR}$.

Statistical analysis was made by Student's t-test for paired comparisons.

\section{Results}

\section{1) Effect of Streptozotocin Treatment on Plasma Glucose and Glucagon}

Streptozotocin produced a moderate diabetic state with wasting, polyuria and moderate hyperglycaemia.

The plasma glucose level before streptozotocin treatment was $78 \pm 4 \mathrm{mg} / 100 \mathrm{ml}$ (mean \pm SEM, $\mathrm{n}=$ $6)$. On the day of operation plasma glucose levels had risen significantly $(2 \mathrm{p}<0.05)$ to $189 \pm 10 \mathrm{mg} /$ $100 \mathrm{ml}$ (mean $\pm \mathrm{SEM}$ ) (range $149-232 \mathrm{mg} / 100 \mathrm{ml}$ ).

Plasma glucagon was also significantly elevated after streptozotocin administration (before: $51 \pm 9$ $\mathrm{pg} / \mathrm{ml}$ - after: $207 \pm 24 \mathrm{pg} / \mathrm{ml}$ (mean $\pm \mathrm{SEM}, \mathrm{n}=$ 6)).

All diabetic dogs exhibited ++ ketonuria.

\section{2) Somatostatin and Glucagon Release from the Perfused Pancreas of Normal and Streptozotocin Diabetic Dogs in Response to Glucose Variations}

The results of perfusion studies with normal and diabetic pancreases during variation of the perfusate glucose concentration are illustrated in Figure 1. In the normal pancreas a decrease in the glucose concentration from 200 to $25 \mathrm{mg} / 100 \mathrm{ml}$ caused an inhibition of somatostatin and a stimulation of glucagon release. Effluent glucagon decreased and somatostatin rose when the perfusate glucose concentration was again increased to $200 \mathrm{mg} / 100 \mathrm{ml}$ 
after $20 \mathrm{~min}$. In contrast to the normal pancreas, somatostatin and glucagon secretion by the diabetic pancreas showed a constant release pattern unresponsive to changes in glucose concentration.

\section{3) Effect of Exogenous Insulin on Somatostatin and Glucagon Release from the Perfused Pancreas}

Perfusions were performed to evaluate a possible direct effect of exogenous insulin on the glucose sensitivity of the D-cell. Exogenous insulin at a concentration of $25,000 \mu \mathrm{U} / \mathrm{ml}$ had no effect on somatostatin and glucagon secretion in control pancreases (Fig. 2, left part) or diabetic pancreases (Fig. 2, right part) at a glucose concentration of $200 \mathrm{mg} / 100 \mathrm{ml}$. Infusion with the same exogenous insulin concentration did not restore the responses of the D- and the A-cell to glucose in the streptozotocin group. The normal group showed a decrement of somatostatin and an increment of glucagon to a decrease in glucose concentration from 200 to $25 \mathrm{mg} / 100 \mathrm{ml}$ independent of the presence of insulin.

To see whether the secretory insensitivity of the D- and A-cell to glucose was selective the effect of arginine $(5 \mathrm{mmol} / \mathrm{l})$, isoproterenol $(2 \mathrm{ng} / \mathrm{ml})$, and calcium $(5 \mathrm{mmol} / \mathrm{l})$ were tested in two experiments in streptozotocin diabetic dogs. Response patterns of somatostatin and glucagon were found which qualitatively were indistinguishable from that of a normal pancreas (Fig. 3).

\section{Discussion}

It is a characteristic feature of normal D- and A-cell function that alterations in glucose concentration induce swift but opposite changes in somatostatin and glucagon release [5-7]. In streptozotocin diabetes, however, we have found that the somatostatin secretion is abnormal, showing no response to perfusate glucose variations (Fig. 1). We also found an absent A-cell response to glucose, in accordance with previous reports [17-19]. Thus there are similarities in the abnormalities of somatostatin and glucagon secretion in experimental diabetes which could both be due to insulin deficiency, as suggested previously for glucagon [20]. However, our results conform with those of Patton et al. [21] in that insulin did not directly affect the release of somatostatin from the isolated, normal pancreas (Fig. 2). Moreover, we did not find any effect of infusion of large amounts of insulin in vitro on the diabetic D- and A-cell abnormality.

It has recently been reported that basal plasma somatostatin levels are higher in insulin-deprived alloxan diabetic dogs compared to insulin-treated ones [22]. The apparent discrepancy between the in vivo and in vitro results concerning the inhibitory effect of insulin on somatostatin secretion is unexplained. It may be that the observed effect of insulin in vivo is secondary to a required insulin induced normalization of tissue metabolism which cannot be effected by short-term exposure in the isolated perfused pancreas preparation. There are similarities here to the abnormal A-cell function found in experimental diabetes. Continuous IV insulin administration can reduce hyperglucagonaemia and restore abnormal glucagon responses to various stimuli in man [20] and animals $[23,24]$ in vivo, while in vitro insulin administration has minor or no effect on basal and glucose stimulated glucagon secretion $[17,19$, 25, 26], as indeed we have found (Fig. 2). It could be speculated that the high glucagon levels obtaining in diabetes may be directly responsible for the increased somatostatin secretion in vivo [10] as glucagon is known to stimulate somatostatin secretion $[8,9]$. However, the present study lends no support for this theory as somatostatin release increases during perfusion of the diabetic pancreas in some situations in spite of a declining glucagon secretion (Fig. 2).

Another possibility is that the abnormal hormone secretion in experimental diabetes is due to a common glucoreceptor dysfunction affecting the B-, Aas well as $\mathrm{D}$-cells. The finding that arginine, the $\beta$ adrenergic stimulator isoproterenol, and calcium stimulate somatostatin secretion normally precludes a generalized insensitivity of the diabetic D-cell and points to a selective insensitivity to glucose in analogy with that found for the B- [27, 28] and A-cells [29].

It is therefore suggested that streptozotocin diabetes is an overall islet cell disease due to a common selective glucoreceptor dysfunction, and that the metabolic abnormalities characterizing the diabetic state may be caused not only by a lesion of the B-cell, but also by a dysfunction of the A- and D-cells. Whether the latter abnormalities are caused by a direct action of streptozotocin or are indirectly secondary to the insulin deficiency as it has been suggested for the A-cell dysfunction in human diabetes mellitus [20] remains to be resolved.

Addendum. After the present manuscript was submitted for publication an interesting study by Hara, M., et al. of alloxan diabetic rats has been published in Life Sciences 24, 625-628 (1979). It was found that basal as well as arginine stimulated somatostatin release from the perfused pancreas of alloxan diabetic rats were augmented significantly, while glucagon secretion in both situations was not significantly different from that attained in normal rats. The effect of glucose was not studied.

Acknowledgements. Cyclic somatostatin for immunization and standards was kindly donated by Norman Grant, Wyeth 
Laboratories, Philadelphia, Pennsylvania; and Roger Guillemin, Salk Institute, La Jolla, California, generously gave $\mathrm{Tyr}^{1}{ }^{1}$-somatostatin for the iodination. Karen Just is thanked for expert technical assistance and Anette Larsen for typing the manuscript. This work was supported by the Danish Medical Research Council. P. Carl Petersen Foundation and a NOVO Research grant.

\section{References}

1. Alberti, K. G. M. M., Christensen, S. E., Iversen, J., SeyerHansen, K., Christensen, N. J., Hansen, Aa. P., Lundbæk, K., Ørskov, $\mathrm{H}$.: Inhibition of insulin secretion by somatostatin. Lancet 1973 II, 1299-1301

2. Iversen, $J .:$ Inhibition of pancreatic glucagon release by somatostatin: In vitro. Scand. J. Clin. Lab. Invest. 33, 125-129 (1974)

3. Adrian, T. E., Bloom, S. R., Hermansen, K., Iversen, J.: Pancreatic polypeptide secretion from the isolated, perfused canine pancreas. Diabetologia 14, 413-417 (1978)

4. Christensen, S. E., Hansen, Aa. P., Iversen, J., Lundbæk, K., Ørskov, H., Seyer-Hansen, K.: Somatostatin as a tool in studies of basal carbohydrate and lipid metabolism in man: Modifications of glucagon and insulin release. Scand. J. Clin. Lab. Invest. 34, 321-325 (1974)

5. Schauder, P., McIntosh, C., Arends, G., Arnold, R., Frerichs, H., Creutzfeldt, W.: Somatostatin and insulin release from isolated rat pancreatic islets stimulated by glucose. FEBS Lett. 68, 225-227 (1976)

6. Ipp, E., Dobbs, R. E., Arimura, A., Vale, W., Harris, V., Unger, R. H.: Release of immunoreactive somatostatin from the pancreas in response to glucose, amino acids, pancreozymin-cholecystokinin, and tolbutamide. J. Clin. Invest. $\mathbf{6 0}$, 760-765 (1977)

7. Hermansen, K., Christensen, S. E., Ørskov, H.: Characterization of somatostatin release from the pancreas. The role of calcium and acetylcholine. Diabetologia 16, 261-266 (1979)

8. Patton, G. S., Dobbs, R., Orci, L., Weil, W., Unger, R. H.: Stimulation of pancreatic immunoreactive somatostatin (IRS) release by glucagon. Metabolism 25, 1499-1500 (1976)

9. Schauder, P., McIntosh, C., Ebert, R., Arends, J., Arnold, R., Frerichs, H., Creutzfeldt, W.: Insulin and somatostatin release and cAMP content of rat pancreatic islets stimulated by glucose and glucagon. Diabetologia 12, 417 (1976)

10. Schusdziarra, V., Dobbs, R.E., Harris, V., Unger, R. H.: Immunoreactive somatostatin levels in plasma of normal and alloxan diabetic dogs. FEBS Lett. 81, 69-72 (1977)

11. Orci, L., Baetens, P., Dubois, M. P., Rufener, C.: Evidence for the D-cell of pancreas secreting somatostatin. Horm. Metab. Res. 7, 400-402 (1975)

12. Patel, Y., Weir, G.: Increased somatostatin content of islets from streptozotocin-diabetic rats. Clin. Endocrinol. (Oxf.) 5, 191-194 (1976)

13. Orci, L., Baetens, D., Rufener, C., Amherdt, M., Ravazzola, M., Studer, P., Malaisse-Lagae, F., Unger, R. H.: Hypertrophy and hyperplasia of somatostatin-containing $\mathrm{D}$-cells in diabetes. Proc. Natl. Acad. Sci. USA 73, 1338-1342 (1976)

14. Iversen, J., Miles, D. W.: Evidence for a feed-back inhibition of insulin on insulin secretion in the isolated perfused canine pancreas. Diabetes 20, 1-9 (1971)
15. Ørskov, H., Thomsen, H. G., Yde, H.: Wick-chromatography for rapid and reliable immunoassay of insulin, glucagon, and growth hormone. Nature 219, 193-195 (1968)

16. Christensen, N. J.: Notes on the glucose oxidase method. Scand. J. Clin. Lab. Invest. 19, 379-384 (1967)

17. Laube, H., Fussganger, R.D., Maier, V., Pfeiffer, E. F.: Hyperglucagonemia of the isolated perfused pancreas of diabetic mice (db/db). Diabetologia 9, 400-402 (1973)

18. Buchanan, K. D., Mawhinney, W. A. A.: Glucagon release from isolated pancreas in streptozotocin treated rats. Diabetes 22, 797-800 (1973)

19. Pagliara, A.S., Stillings, S. N., Haymond, M.W., Hover, B. A., Matschinsky, F. M.: Insulin and glucose as modulators of the amino acid-induced glucagon release in the isolated pancreas of alloxan and streptozotocin diabetic rats. J. Clin. Invest. 55, 244-255 (1975)

20. Aydin, I., Raskin, P., Unger, R. H.: The effect of short-term intravenous insulin administration on the glucagon response to a carbohydrate meal in adult onset and juvenile diabetes. Diabetologia 13, 629-636 (1977)

21. Patton, G., Ipp, E., Dobbs, R., Orci, L., Vale, W., Unger, R. H.: Pancreatic immunoreactive somatostatin release. Proc. Natl. Acad. Sci. USA 74, 2140-2143 (1977)

22. Schusdziarra, V., Ipp, E., Harris, V., Dobbs, R. E., Raskin, P., Orci, L., Unger, R. H.: Studies of the physiology and pathophysiology of the pancreatic D-cell. Metabolism 27, 1227-1232 (1978)

23. Dunbar, J. C., Walsh, M. F., Foa, P. P.: The serum glucose response to glucagon suppression with somatostatin, insulin or antiglucagon serum in depancreatized rats. Diabetologia 14, 53-58 (1978)

24. Blasquez, E., Munos-Barragan, L., Patton, G. S., Orci, L., Dobbs, R. E., Unger, R. H.: Gastric A-cell function in insulindeprived depancreatized dogs. Endocrinology 99, 1182-1188 (1976)

25. Buchanan, K. D., Mawhinney, W. A.: Insulin control of glucagon release from insulin-deficient rat islets. Diabetes 22, 801-803 (1973)

26. Samols, E., Harrison, J.: Evidence for a negative insulin-glucagon feedback. Diabetes 24 [Suppl. 2], 442 (1975)

27. Deckert, T., Lauridsen, U. B., Madsen, S. N., Mogensen, P.: Insulin response to glucose, tolbutamide, secretin and isoprenaline in maturity-onset diabetes mellitus. Dan. Med. Bull. 19, 222-226 (1972)

28. Robertson, R. P., Porte, D.: The glucose receptor: a defective mechanism in diabetes mellitus distinct from the beta adrenergic receptor. J. Clin. Invest. 52, 870-876 (1973)

29. Gerich, J. E., Langlois, M., Noacco, C., Lorenzi, M., Karam, J. H., Forsham, P. H., Gustafson, G.: Comparison of the suppressive effects of elevated plasma glucose and free fatty acid levels on glucagon secretion in normal and insulin-dependent diabetic subjects. J. Clin. Invest. 58, 320-325 (1976)

Received: March 3, 1979,

and in revised form: July 24, 1979

K. Hermansen

Second University Clinic of Internal Medicine

Kommunehospitalet

DK-8000 Aarhus C

Denmark 